\title{
IMPROVING STUDENTS' READING COMPREHENSION ACHIEVEMENT IN NARRATIVE TEXT THROUGH EXPERIENCE- TEXT- RELATIONSHIP
}

\author{
(ETR) METHOD
}

*Dessy Natalia Samosir

**Meisuri

\begin{abstract}
This study focuses on the improvement of students' reading comprehension achievement in narrative text through Experience-Text-Relationship (ETR) Method. This study deals with classroom action research which was done in 6 meetings. The subject of this study was the second grade of SMP N 41 Medan, class VIII ${ }^{5}$. One class is totally taken as the subject of this study. The number of the sample is 34 students. The data of this study were obtained from the reading test, observation sheet, and diary notes. Based on the analysis data, it was found that the students' achievement improved from the orientation test, test cycle I, and test cycle II. The findings of this study indicated that Experience- Text- Relationship (ETR) Method improved the students' reading comprehension achievement. The students' mean scores showed significant improvement, the mean of Cycle I $=64,38$ and the mean of Cycle II $=77$, 20.
\end{abstract}

Keywords: Reading Comprehension, Narrative Text, Experience-Text-Relationship (ETR) Method

\footnotetext{
* A graduate of English Language and Literature Department of UNIMED

** A lecturer of English Language and Literature Department of UNIMED
} 


\section{INTRODUCTION}

\section{Background of the Study}

English like many other languages consist of four skills, namely: listening, speaking, reading, and writing. Reading is one of the most important language skills to be taught to the students, because it is very useful for the students. Reading is needed to get the information from what has been read.

Grabe and Stoller (2002:9) state that reading is a way to draw information from the printed page and interpret the information appropriately. In this process, the prior knowledge is very important and needed by the students. As Eisterhold (1998) states that prior knowledge or often called as "schema" is absolutely essential for reading and also needed in the reading process.

Absolutely, every student having the prior knowledge. But, each of them carries different schema or prior knowledge. But, in the fact most of the students still get a lack in activating their prior knowledge during the reading process, specifically in reading with comprehension. As the result, the students often get difficulties in comprehending the reading text. This evidence is supported by the writer's experience during the writer's experience in the first observation or mini research in SMP N 41 Medan. Most of the students were still in low level of reading comprehension. It is difficult for the students to comprehend English text. When the teacher told them to tell some information from the reading text, most of them didn't have any ideas to tell some information from what they've read.

Thus, to overcome the problem above, the teacher should consider the most effective method or strategy to improve the students' reading comprehension in reading the text. There are some alternative strategies that often used in improving the students' reading comprehension, such as : Reciprocal Teaching Strategy (Palincsar and Brown, 1984), Semantic Mapping Strategy ( Pittleman and Heimlich, 1986), Experience- TextRelationship Method ( Au,K.H, 1977), Story Pyramid Strategy (Bailey and Clire, 2001), and Directed-Thinking-Activity strategy (Russel Stauffer, 1998).

Considering about solving the problems above, the writer applied ExperienceText-Relationship (ETR) Method to improve the students' reading comprehension achievement in narrative text. 
ETR Method is one kind of metacognitive strategies. It is one of the best methods in teaching reading comprehension. Carrell et al (1989: p 647) states that this Experience-Text-Relationship (ETR) method emphasizes comprehension in reading for meaning. This ETR method can help the students to activate their background of knowledge in drawing the meaning of a text or story. Then, related it to the new information that they've got from the text after reading process.

There have been some previous researchers conducted researches by applying this ETR Method. Au (1977) had used this ETR method to teach reading comprehension in EFL for Hawaiian children. It was used to stimulate or activate the students' prior knowledge while reading process. After applying this method to the students, the reading test was administrated to see the effect of this ETR Method in Hawaiian children' reading comprehension. And test results of Hawaiian children who have been instructed with the ETR Method seem to indicate the improvement of their achievement. The ETR method provides the children opportunities to explore many dimensions of the story and to integrate features of it with their existing store of knowledge. They become more active during the reading process. They just not read the text, but rather than reading for detailed comprehension. As the result, they show better reading comprehension than the children who have not been instructed with the ETR Method in their reading comprehension.

Additionally, Carrell et al. (1989) also conducted a study in the L2 (second language) by applying the ETR Method to High-intermediate level adult ESL students. The students were trained in the experience-text-relationship (ETR) method to activate their background knowledge. Results showed that the ETR Method was effective in enhancing reading comprehension.

\section{Research Question}

The problem of the study is formulated as: "Does the ETR Method significantly improve students' reading comprehension achievement in narrative text?" 


\section{The Scope of the Study}

This study focuses on the application of Experience-Text-Relationship (ETR) Method to improve students' reading comprehension in narrative text of the second year (Grade VIII) of SMP N 41 Medan

\section{The Objective of the Study}

The objective of the study is to discover whether the ETR Method could significantly improve the students' of SMP N 41 Medan reading comprehension achievement in narrative text.

\section{The Significance of the Study}

The findings of the study are expected to be useful for:

- Teachers who want to develop their proficiency in teaching reading, especially in reading narrative text.

- Readers, who are interested in doing further research related to this study.

\section{THEORETICAL FRAMEWORK}

\section{Reading Comprehension}

Reading comprehension is the act of understanding of a text. It is an intentional, active, interactive process that occurs before, during and after a person reads a particular piece of writing. Lorraine and Anne (2004: 253) define that reading comprehension is an important academic skill. It is the process of simultaneously extracting and constructing meaning through involvement with written language.

Reading with comprehension means understanding what has been read. It is an active, thinking process that depends not only on comprehension skills but also on the student's experiences and prior knowledge. Comprehension is a construction process because it involves all of the elements of the reading process working together as a text which is read to create a representation of the text in the reader's mind. Comprehension is powerful because the ability to construct meaning comes from the mind of the reader. 
In line with, John Lagan (2002: p 359) states that one misleading idea that some students have about reading is that comprehension should happen all at once. But, what such students do not realize is that good comprehension is usually "a process". Very often, comprehension is achieved gradually, as we move from a general feeling about something means to deeper level of understanding.

\section{Narrative Text}

Narrative text is one of genres of text. It is also a common type of texts. There are some genres of text, such as: descriptive, procedure, narrative, recount, and report. According to Rothery (quoted in Tickoo, 1995), narrative text is essentially a story with events that constitute problem for one or more characters who are motivated to confront and solve the problem.

The social function of narrative text is to amuse, entertain and deals with actual or vicarious experience in different ways ( Gerot and Wignell, 1994 : 204).

\section{The types of narrative text}

\section{Fiction}

Narrative can be said as a fiction if the story is untrue and not happened in the real world. Fiction includes folk tales, fairy tales, and myths.

2. Non-Fiction

Narrative is called non-fiction if the story or event is true and actually occurred. Non fiction is often factual stories, biography, and history.

\section{The generic structure of Narrative text:}

According to Gerrot and Wignell (1994: 204), the generic structure of narrative text is as follows:

\section{Orientation}

This element usually describes scene or the problematic events. It also tells the readers the characters who were involved and where it was happened.

\section{Evaluation}

This element contained the sequences of events, which is talk about the activity or event on the past.

\section{Complication}

This element of an event that talks about the crisis that arises. 
4. Resolution

This element contained of an event that talks about the crisis is resolved (problem solving); even it is for better or worse.

5. Re-orientation

This element contained of a brief summary, which is aimed to give or submit a moral lesson to the readers.

\section{Language Features of Narrative Text}

Gerot and Wignell (1994: 2004) suggest language features of narrative text. Narratives focuses on specific and individualized participants with define identities;

1. They can be written in the first person or third person.

2. They use temporal conjunction and temporal circumstances that describe time and place.

3. They use past tense.

4. They use material process (action verb) and some behavioral and verbal process; Behavioral process usually describes process of physiological and psychological behavior, such as dreaming, smiling, breathing, and etc. verbal process is usually described as the process of saying, such as, telling, warning, talking, and etc.

5. They use relational process of doing or showing what happened and what someone do or what is done ; Relational process is a process of being and having that can be classified whether to identify something and to assign a quality of something; whereas, mental process is process of sensing, such as thinking, feeling, and perceiving.

\section{Experience - Text - Relationship (ETR) Method}

Experience-Text-Relationship Method is a method of teaching. It is also a kind of metacognitive strategies that can be applied in teaching reading comprehension. 
Beside of the ETR Method, there is also some method or strategies that are often used in improving students' reading comprehension, such as: Reciprocal Teaching Strategy, Directed- Reading- Thinking- Activity (DRTA), SQ3R Method, K-W-L Strategy, and etc. All those strategies are a part of metacognitive strategy. As Crawley (1946: p 66) the term metacognitive means having a knowledge or understanding of our thought process. It means being able to identify our purposes for reading and being able to monitor or check our understanding while reading.

As Carrel et al (1989, p. 647) state the Experience-Text-Relationship (ETR) method emphasizes comprehension, in reading for meaning. ETR was found to be an effective method for helping students to use their background knowledge ( $\mathrm{Au}, 1979)$.

The E-T-R method first draws on the children's background knowledge and experience. English language learners particularly need the Experience-TextRelationship (ETR) method because they need the background knowledge to comprehend the language, includes foreign language.

The experience-text-relationship (ETR) consists of students' expressing their own experience of knowledge about the topic prior to reading. After the students have adequately shared their knowledge; the text becomes the focus of the class. During this segment of the lesson, the teacher asks the students to read short sections of the text and then questions about the content. In the final stage, the teacher aids the students to draw relationships between personal experiences and the material discussed in the text stage. This provides an opportunity for each student to make comparisons and contrasts with what they already know and to accommodate the new information into their preexisting schemata.

This ETR Method provides teachers a way to systematically guide their students through the reading process, monitor their students' comprehension, and guide them to the correct answers when needed. It can be applied in order to support the students in their reading comprehension. This ETR Method also can be used as a way of using the child's experiences to promote reading achievement.

\section{Experience-Text-Relationship (ETR) Method Design Frame Work}

ETR was found to be an effective method for helping students to use their background knowledge ( $\mathrm{Au}, 1979)$. It has three essential phases; 
a. Experience (E): In this first step, the teacher starts a discussion to activate students' background knowledge about the topic of the passage to be read and to motivate them to read.

b. Text (T); in the second step, the teacher asks the students to read short parts of the text and asks questions on the content of the text. In this way, the teacher tries to make sure that they understand what they read.

c. Relationship (R); in the third step (R), the students are encouraged to relate the content of the text to their personal experiences and knowledge. In other words, they are encouraged in personal engagement. During the reading of the texts, the teacher tries to model the cognitive processes involved in the comprehension of the text. In this $R$ sequences the teacher attempts to draw relationships for the children between the content of the story discussed and their outside experience and knowledge.

\section{METHODOLOGY}

\section{Research Design}

The research was conducted by applying the action research. It was focused on classroom action research (CAR). It aimed at developing certain instructional strategy to solve practical instructional problems in classroom. According to Kumar (2006: 261) Action research is a method for improving and modifying the working system of a classroom in school. The teachers and students were able to study their problems of teaching scientifically. It was an objective oriented method.

Classroom action research was applied in this study in order to see the improvement of students' reading comprehension achievement in narrative text through the Experience- Text-Relationship (ETR) Method.

There were four phases for each action research cycles, namely: planning, action, observation, and reflection. If the result failed, it continued to the next cycle by revising the previous steps to find the problem solving. The next cycle was expected to improve all the teaching learning process; in order the students' achievement got an improvement. If the next cycles increased students' learning achievement, the cycle was stopped. If it didn't increase the students' learning 
achievement, the cycle should be continued on and on to the next cycle until the students' achievement as the main goal was reached.

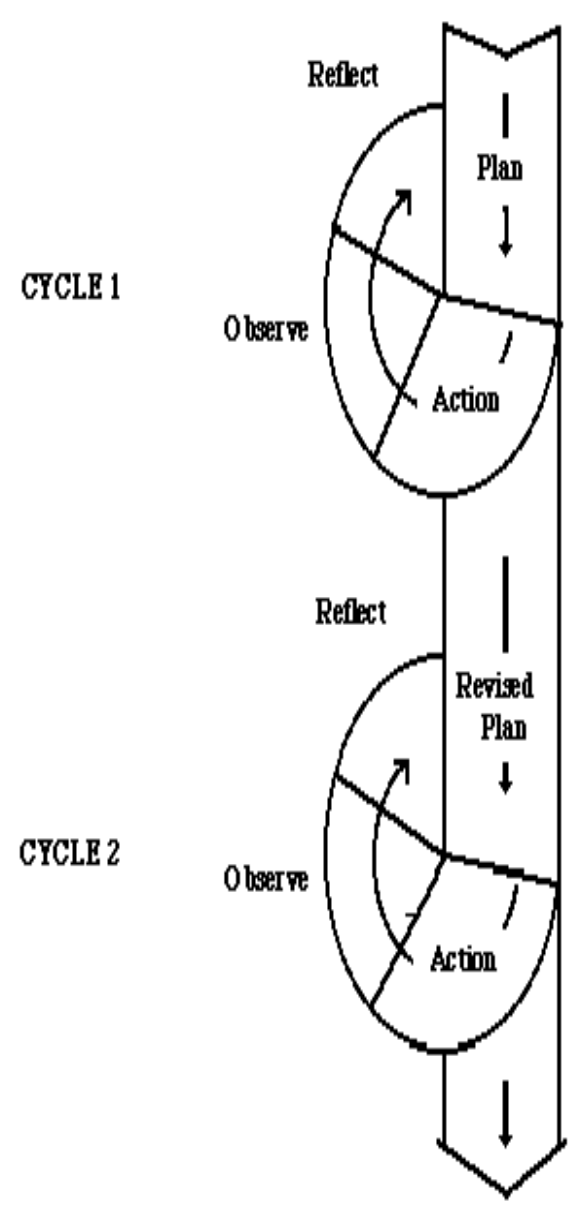

Figure 1: Simple Action Research Model

(Kemmis and Mc. Taggart, 1998)

1. Planning

Planning was an arrangement of doing something.

2. Action

Action was the process of activity that is done in teaching learning process. It was implementation of planning.

3. Observation 
In observing systematically the effects of the action and documenting the context, actions and opinions of those involved. It was a data collection to collect information about what is happening.

4. Reflection

At this point, reflect on, evaluate and describe the effects of the action in order to make sense of what had happened and to understand the issue that had explored more clearly.

\section{Subject}

The subject of this research was the second grade students of SMP N 41 Medan. There were four parallel classes of grade VIII, they were: $\mathrm{VIII}^{1}, \mathrm{VIII}^{2}, \mathrm{VIII}^{3}$, $\mathrm{VIII}^{4}$, and VIII $^{5}$. The class that taken for this research is VIII E. The total number of this class was 34 students which consisted of 15 male and 19 female.

\section{Data Collection}

This study collected quantitative and qualitative data. The quantitative data was collected through students' scores from the reading test that was administrated by the researcher.

In qualitative data, the researcher used observation sheet and diary note to collect the data as qualitative data.

\section{RESULTS AND DISCUSSION}

In the research, the data were collected from quantitative and qualitative data. The qualitative data were analyzed from observation sheet and diary notes, while the quantitative data were taken from the scores of reading test during conducted research in six meetings. The reading test was given each meeting, but the students' reading score were only taken from the second, fourth, and sixth meeting.

The students' scores increased from orientation test, cycle I test, and cycle II test. In the first treatment (cycle 1 test), the mean of the students' total score was below standard (KKM). It was reflected by the mean of the students' score in the cycle 1 test that was just 63,38 . There are some cases that were analyzed in observation sheet and 
diary notes why are the mean of the students' total score below standard (KKM). The first, when the teacher explained the material, most of the students didn't listen to teacher's explanation attentively because they didn't like study English. The second, the students looked confusing with the new method that applied in the teaching learning process. So, all those conditions made the students not enjoyed the learning process and most of them been passive in the class.

In the cycle II, the mean score of the students had improved above standard and the whole students' score had standard (65) too. In this cycle, the lacks of the researcher in cycle I had been improved and as the result the score and mean of the students improved above standard (KKM). In this cycle, the students' score had been improved. So, the mean of the students score was 77, 20 and the whole students got above standard (KKM). The students' improvement was also reflected from observation sheet and diary notes.

Based on observation sheet, the whole conditions that were happen during the teaching and learning process had better than the cycle I. The teacher taught the material based on lesson plan so the material was taught systematically. This observation sheet showed that the students were more active in teaching learning process, they listen to teacher's explanation attentively and the students brave in giving their opinion and also gave good responses in answering some questions that given by the researcher.

Based on the researcher' notes in diary notes, it showed that the students also showed the improvement in their condition. The students felt enjoy and comfortable in following the lesson. The students were more active because they got easier in comprehending the material by using ETR Method so they enthusiast in learning process. In doing the test, they looked more confidence in answering the questions.

From the analysis above, the researcher found improvement in the students mean, condition and feelings. The mean of the students score improved from cycle 1 $(63,38)$ to cycle II $(77,20)$. It was also supported by the qualitative data, from observation sheet and diary notes. It showed that the students' conditions and feelings were more active in the class during the learning process. The students were easier to comprehend the materials. 
As summary, It can be concluded that the Experience - Text- Relationship (ETR) Method had successfully improved the students' reading comprehension achievement in narrative text.

\section{CONCLUSION AND SUGGESTIONS}

\section{Conclusion}

After analyzing the data, the researcher found that students' achievement in reading comprehension improved from the cycle I until cycle II. It was showed by the mean of students' score of reading test in cycle I $(63,38)$, and reading test in cycle II $(77,20)$. The students' score continuously improved in each reading test. It means that there is an improvement toward students' achievement in reading comprehension through ETR Method. It is supported by the qualitative data; observation sheet and diary notes. It showed that the students also felt more enjoyable and interested in reading comprehension by using ETR Method. Therefore, it can be concluded that ETR Method significantly improves students' achievement in reading comprehension.

\section{Suggestion}

The study showed that the use of ETR Method could improve the students' achievement in reading comprehension. Based on the conclusion above, some suggestions are pointed out as follows:

1. The English teachers are suggested to use the ETR Method to make the teaching- learning more interesting and active particularly in reading narrative text because this method is designed to explore the students' background knowledge in comprehending the text they read.

2. The readers who are interested for further study related to this research should explore the knowledge to enlarge their understanding about how to improve students' achievement in narrative text and search another references. 


\section{REFERENCES}

$\mathrm{Au}$, K.H. 1977. Cognitive training and reading achievement. Paper presented at the annual meeting of the Association for the Advancement of Behavior Therapy. Atlanta.

Betsy, Parish. 2004. Teaching Adult ESL. New York: Hamline University

Brown, H.D.2000. Principles of language learning and teaching. New York:

Longman.

Burns, Paul.C.1984. Teaching Reading In today's Elementary Schools.Knoxville: Tennese University.

Clark and Clark. 1977. Psychology and Language. An Introduction to Psycholinguistics. New York: Harcourt Brace Jovanovich.

Gilakjani, P.A. \& Ahmadi, M.S. 2011. The Relationship between L2 Reading Comprehension and Schema Theory: A Matter of Text Familiarity,

International Journal of Information and Education Technology, vol 1,142-140. http: //www.interesjournals.org./ER.Retrieved April 29, 2012.

Grabe, W. and Stoller, F.L.2002.Teaching and Researching Finding. Edinburg: Pearson Education.

Harmer, Jeremy. 1998. How to teach English. Cambridge: Longman.

Harmer, Jeremy. 2004. How to teach writing. England: Pearson Education Limited. 
http:///www.signgenius.com/sign-language/definition-of-language.html,Accessed on June 2, 2012.

Kendeou, P. \& VandenBroek, P.2007. The Effects of Prior Knowledge and text structure on comprehension process, vol 7, 1567-1577. http://www.journal/electronic journal.htm. Retrieved April 29, 2012.

Ming Chou, P.T.2011. Effects of Vocabulary Knowledge and Background Knowledge on Reading Comprehension of Taiwanese EFL Students. Taiwan: Wenzao Ursuline College of Languages.

http: //www.electronic journal.htm. Retrieved April 302012.

Nunan, David. 1999. Second Language Teaching and Learning. Hong Kong: University.

Taboada, A. and Guthrie, T.J., 2006. Contributions of Student Questioning and Prior Knowledge to Construction of Knowledge from Reading Information Text, Journal of Literacy Research, vol 1, $1-35$.

http://jlr.sagepub.com/content/38/1/1. Retrieved April 26, 2012.

Wallace, Michael .J. 1998. Action Research for Language Teachers. United Kingdom: Cambridge University.

Wallace, J. Michael. 1980. Study skills in English. Cambridge: University Press.

Wong, B.Y.L.2004.Learning about Learning Disabilities. Canada: Elsevier Academic Press. 
